\title{
Phytochemical Analysis and Antibacterial Activities of Terminalia pallida against Bacillus subtilis, Klebsiella pneumoniae, Proteus vulgaris, and Pseudmonas aeruginosa
}

\author{
M. John Paul ${ }^{1}$, Dr. Ek. Dorcas Joy ${ }^{2}$, Dr. SKM. Basha ${ }^{3}$ \\ ${ }^{1}$ Research Scholar, Research and Development Centre, Bharatiar University, Coimbatore, Tamilnadu, India \\ ${ }^{2}$ Lecturer in Botany, D. K. Government College (A), Nellore Dt, Andhra Pradesh, India \\ ${ }^{3}$ Department of Botany, Vikrama Simhapuri University, Kavali, Nellore Dt, Andhra Pradesh, India
}

\begin{abstract}
Indian medicine is known as the richest, the first and the foremost among other branches of medical knowledge that is available elsewhere on the globe. Much of the information was amply recorded by experienced individuals of this art. The earliest written record of the preparation and use of medicine from plants is in the Rig-Veda, Atharvanaveda documented more details on medicinal herbs and their varied utility. Throughout the history of man, plant drugs have played a vital role in healing and curing illness. Many indigenous methods were in use for centuries to treat various ailments. To elevate the medicinal properties, Different parts of Terminalia pallida were collected from different localities of Veligonda hill range, Eastern Ghats, Nellore Dt, Andhra Pradesh, India. The methanolic extracts of various parts of the plants were qualitatively screened for phytochemicals by using standard procedures which revealed the presence of various important bioactive chemical entities. Antibacterial activity of the methanolic extracts of stem bark and fruit were evaluated against Bacillus subtilis, Klebsiella pneumoniae and Proteus vulgaris, Pseudomonas aeruginosa. The methanolic extracts of these plant parts have exhibited significant broad spectrum antibacterial activities.
\end{abstract}

Keywords: Stem bark, Antibacterial, Bioactive

\section{General Introduction}

Organic analytical study is one of the important and rapidly extending areas of plant drugs useful in pharmacognostical studies. The study helps in standardizing and differentiating the drugs and to provide adequate data for laying down pharmacopoeial standards. The Phytochemical evaluation of the selected crude drugs involves 1) organic analysis for active principles and 2) chromatography of different extracts.

\section{Preliminary Phytochemical studies}

\section{Introduction}

Phytochemical constituents are the basic source for the establishment of several pharmaceutical industries. The constituents present in a drug or plant play a significant role of crude drug. It is a qualitative chemical evaluation which indicates spectrum of chemical constituents present in a plant drug. Thus the Phytochemical screening is very important in identifying new sources of therapeutically and industrially important compounds like alkaloids, flavonoids, phenolic compounds, saponins, steroids, tannins, terpenoids etc. In pharmacognostical study, detection of these active principles are of great importance since many plant based drugs like aconite, atropine, brucine, caffeine, codeine, colchicines, digitoxin, digoxin, ephedrine, morphine, papaverine, pilcorpine, physostigmine, protopine, quinine, reserpine, scopolamine, strychnine, vinblastine, vincristine and taxol are widely used now-a-days in medicine for production of various pharmaceutical drugs. $n$ general the organic compounds in plants can be categorised into three groups viz., primary metabolites, secondary metabolites and semantides. The primary metabolites (carbohydrates, proteins, lipids, cellulose and chlorophyll) are the basic constituents of the plant. They occur universally in the plant and play a vital role in the function of cell.

The compounds that are responsible for therapeutic effect are usually the secondary metabolites. These are selective and accumulate in the various parts of the plant cells. They synthesize either for a particular plant or may be translocated from other areas of active synthesis in the plant. Semantides are the information carrying molecules. DNA is primary, RNA is secondary and proteins are tertiary semantides.

\section{Plant Material Collection}

During the exploration of ethno-medico-botanical survey, the stem bark and fruits of Terminalia pallida were collected from different localities of Veligonda hill range, Eastern Ghats, Nellore Dt, Andhra Pradesh, India. These plant parts (Stem bark and fruit) were thoroughly washed with water and sufficient quantity of samples collected and chopped off into small fragments and shade dried. The dried samples were ground to make coarse powder (each $1 \mathrm{~kg}$ ) and stored in polythene containers at room temperature. These samples were used for the detection of various secondary metabolites. Phytochemical screening was done following standard procedure adopted by Harborne (1973) and Gibbs (1974).

\section{Volume 6 Issue 12, December 2017}




\section{International Journal of Science and Research (IJSR) \\ ISSN (Online): 2319-7064}

Index Copernicus Value (2016): 79.57 | Impact Factor (2015): 6.391

\section{Experimental Studies}

Alkaloids test: The methanolic extract was evaporated to dryness and the residue obtained was digested with $1 \%$ Hydrochloric acid. The resulting acidic solution was divided into two parts. To one part was added Mayer's reagent and to the second part dragendorff's reagent. Appearance of precipitate or turbidity indicates the presence of alkaloids.

\section{Preparation of reagents}

1) Mayer's reagent: $1.3 \mathrm{~g}$ of Mercuric chloride and $5 \mathrm{~g}$ of Potassium iodide were dissolved separately in $60 \mathrm{ml}$ and $10 \mathrm{ml}$ of double distilled water and both the solutions were mixed and diluted to $100 \mathrm{ml}$.

2) Dragendorff's reagent: $8 \mathrm{~g}$ of the Bismuth nitrate was dissolved in $20 \mathrm{ml}$ of conc. nitric acid and $27.2 \mathrm{~g}$ of Potassium iodide in $50 \mathrm{ml}$ of double distilled water. Both the solutions were allowed to stand till $\mathrm{KIO}_{3}$ crystallized out. Supernatant was decanted and final volume was adjusted to $100 \mathrm{ml}$.

3) Flavonoids: The plant extract was tested for flavonoids by shinoda's reaction. To a few $\mathrm{ml}$ of Methanolic extract, conc. Hydrochloric acid, Magnesium powder and a few fragments of $\mathrm{Mg}$ metal was added. The presence of flavonoids was identified by the development of pink or magenta or red coloured flame.

4) Terpenoids (Liebermann - Burchard's test): The Liebermann-Burchard's reaction was carried out by adding $0.5 \mathrm{ml}$ of $\mathrm{H}_{2} \mathrm{SO}_{4}$ along the side of the test tube containing a mixture of Methanolic $\mathrm{HCl}$ and Acetic anhydrate $(0.5 \mathrm{ml}$ each $)$. Formation of colour from green to bluish-green (sometimes via red or blue) indicate the presence of terpenoids.

5) Steroids (Salkaowski reagent): Development of wine red colour on adding con. $\mathrm{H}_{2} \mathrm{SO}_{4}$ and $\mathrm{CHCl}_{3}$ to the Methanolic extract indicate the positive test for steroidal compounds.

6) Lignans: The plant extract was tested for the presence of lignins by adding conc. $\mathrm{HCl}$ and $2 \%$ Forfuraldehyde. Development of red colour indicates the presence of lignans.

7) Indoles: The development of voilet colour in the methanolic extract on adding Ehrilich reagent is considered as a positive reaction test.

8) Carbohydrates (Molisch test): To the methanolic extract, $\alpha$-napthol solution $(1.0 \mathrm{~g}$ dissolved in $100 \mathrm{ml}$ of each ethanol w/v) was added. Then Conc. $\mathrm{H}_{2} \mathrm{SO}_{4}$ was added gentlyalong the walls of the inclined test tube. Formation of a red to voilet colour indicate the presence of carbohydrates.

9) Test for reducing sugars: To $5 \mathrm{ml}$ of Benedict's reagent, $5 \mathrm{ml}$ of the test solution was added. The tubes were incubated in boiling water on water bath for 10-30 minutes. The development of an orange red precipitate indicates the presence of reducing sugars.

10) Protiens (Million's test): Million's reagent (solution of Mercuric nitrate in nitric acid) was added to $20 \mathrm{ml}$ of boiling Methanolic extract. Formation of white precipitate that gradually turns red upon heating was observed for the presence of proteins.

11) Phenolic compounds: To the test solution 1-4 drops of $1 \%$ Ferric chloride was added. Appearance of intense colour in the extract was observed for the presence of phenolic compounds.

12) Anthocyanidins: The formation of red or purple colour with the plant extract, on adding equal volume of Methanolic $\mathrm{HCl}$ was taken as a positive reaction for anthocyanidins.

13) Anthraquinones: $20 \mathrm{ml}$ of benzene was added to $5 \mathrm{~g}$ of plant powder and filtered. To the filtrate $5 \mathrm{ml}$ of $10 \%$ Ammonium hydroxide solution was added and shaken well. The formation of pink, red or violet colour in the ammonical phase indicates the presence of anthraquinones (Wall et $\alpha$ l., 1954 anf Frans Woath, 1966).

14) Saponin test: The plant extract was evaporated to dryness. Tap water was added and shaken vigorously in a graduated cylinder for 15 minutes. Formation of a persistent foam was taken as a positive reaction test.

15) Tannins: The Methanolic extract was concentrated and the residue was dissolved in water and tested with $1 \%$ Gelatin solution and $1 \%$ Gelatin salt solution (1g gelatin dissolved in $10 \mathrm{~g} \mathrm{NaCl} \mathrm{w/w)} \mathrm{to} \mathrm{separate} \mathrm{volumes.} \mathrm{The}$ appearance of white precipitate indicates the presence of tannins.

Table 1 (a): Preliminary Phytochemical screening of Terminalia pallida (Methanolic Extract)

\begin{tabular}{|l|c|c|}
\hline \multirow{2}{*}{ Compoud } & \multicolumn{2}{c|}{ Terminalia pallida } \\
\cline { 2 - 3 } & Stem Bark & Fruit \\
\hline Alkaloids & - & - \\
\hline Flavonoids & + & + \\
\hline Indoles & + & + \\
\hline Leucoantho-cyanins & + & - \\
\hline Steroids & + & - \\
\hline Carbohydrates & + & + \\
\hline Phenols & + & + \\
\hline Steroidal nucleus & + & - \\
\hline Saponins & + & + \\
\hline Tannins & + & + \\
\hline Proteins & + & + \\
\hline Lignins & + & + \\
\hline Methylenedioxy functional compounds & - & - \\
\hline
\end{tabular}

\section{Screening for Selective Secondary Constituents}

\section{$\underline{\text { A. Phenolic compounds }}$}

\section{a) Extractive procedure}

The phenolic constituents were extracted by following the method given by Bate Smith (1954) and Ibrahim and Towers (1960). About $25 \mathrm{~g}$ of healthy plant material was macerated with $100 \mathrm{ml}$ of $2 \mathrm{~N}$ Hydrochloric acid.(HCL). The homogenate was digested on a boiling water bath for about half-an-hour. The contents were cooled and filtered through Whatman No.1 filter paper. The filtrate was extracted repeatedly with peroxide free diethyl ether. All the extracts were pooled and concentrated to $100 \mathrm{ml}$ and was treated three times with $25 \mathrm{ml}$ of $5 \%$ anhydrous sodium carbonate solution. The pooled carbonate solution was adjusted to $\mathrm{pH}$ 2.0 with Conc. Hydrochloric acid.

The acidified fraction at $\mathrm{pH} 2.0$ was extracted with equal volumes $(25 \mathrm{ml})$ of fresh diethyl ether thrice. The combined 


\section{International Journal of Science and Research (IJSR) \\ ISSN (Online): 2319-7064}

Index Copernicus Value (2016): 79.57 | Impact Factor (2015): 6.391

other extracts were washed with distilled water repeatedly till all traces of hydrochloric acid was removed. The ether soluble water was removed by freezing the extract. The ether was evaporated to dryness on water bath at $98^{\circ} \mathrm{C}$ and the resulting phenolic compound residue was dissolved in $1 \mathrm{ml}$ of $95 \%$ ethanol. This was stored at low temperature in dark container for ready use.

\section{b) Identification}

About $2 \mathrm{~g}$ of fresh weight equivalent to the final alcoholic extract was spotted on 23 x $29 \mathrm{~cm}$ whatmann No.1 Chromatographic filter paper with the help of micro pipette. The origin of the spot area was dried immediately with the help of hair-drier. Two dimensional ascending Chromatographic technique was adapted with benzeneacetic acid-water $(60: 70: 30 \mathrm{v} / \mathrm{v} / \mathrm{v}$, upper layer) in the direction and sodium formate-formic acid-water (10:1:200 $\mathrm{w} / \mathrm{v} / \mathrm{v})$ in the second direction. The Chromatographic chambers were saturated with the above solvent systems one day before the development of the Chromatograms at 22 to $24^{0} \mathrm{c}$. The sheets after development were removed from the chambers and dried at room temperature. The dried sheets were observed under Ultra violet light and fluorescent regions were marked. The papers while exposing to Ammonia vapours were also observed under UV light and new fluorescent spots were marked.

The separated phenolic compounds on the Chromatograms were identified by comparison of $R_{f}$ values and individual spot colours of Chromogenic sprays. The final confirmation was made with authentic samples by co-chromatography.

\section{c) Chromogenic spray reagents}

\section{i) Diazotized sulphanilic acid reagent}

$25 \mathrm{ml}$ of freshly prepared $5 \%$ sodium nitrate was slowly added to $5 \mathrm{ml}$ of sulphanilic acid solution $(900 \mathrm{mg}$ of sulphanilic acid was dissolved in $9 \mathrm{ml}$ of Conc. $\mathrm{HCl}$ and the solution was diluted to $100 \mathrm{ml}$ with $\mathrm{H}_{2} \mathrm{O}$ ) at $0^{\circ} \mathrm{c}$. To intensify the colours of the developed spots, 20\% Sodium Carbonate solution was sprayed to the wet sheets (sprayed at $0^{\circ} \mathrm{c}$ immediately after spraying the above solution).

\section{ii) Diazotized $p$-Nitraniline reagent}

$10 \mathrm{ml}$ of $p$-nitraniline reagent $(1.5 \mathrm{~g}$ of $p$-nitraniline was added to $45 \mathrm{ml}$ of Conc. $\mathrm{HCl}$ and was made up to $950 \mathrm{ml}$ with distilled water) was mixed with $0.2 \mathrm{ml}$ of $5 \%$ Sodium nitrate and $10 \mathrm{ml}$ of $10 \%$ Sodium carbonate solution.

Table 1b: Phenols

\begin{tabular}{|c|c|c|}
\hline \multirow[t]{2}{*}{ Compoud } & \multicolumn{2}{|c|}{ Terminalia pallida } \\
\hline & Stem Bark & Fruit \\
\hline Digallic acid & + & + \\
\hline Gallic acid & + & + \\
\hline Ellagic acid & - & + \\
\hline Aesculetin & - & - \\
\hline Cis-p-coumaric acid & - & - \\
\hline iso-chlorogenic acid & - & - \\
\hline Chlorogenic acid & + & + \\
\hline Caffeic acid & - & - \\
\hline Protocatechuic acid & + & + \\
\hline Gentistic acid & - & - \\
\hline Scopoletin acid & - & - \\
\hline Phloretic acid & + & + \\
\hline$\rho$-Hydroxy benzoic acid & + & + \\
\hline$\alpha$-Resorcyclic acid & + & + \\
\hline$\beta$-Resorcyclic acid & - & + \\
\hline trans- $\rho$-coumaric acid & + & - \\
\hline Vanillic acid & + & + \\
\hline Pcoumarylquinic acid & + & - \\
\hline Cis- $\rho$-coumaric acid & + & + \\
\hline Melilotic acid & + & - \\
\hline Cis-Ferulic acid & + & + \\
\hline trans-Ferulic acid & + & - \\
\hline Coumarin & + & + \\
\hline Salycyclic acid & + & - \\
\hline Cinnamic acid & + & + \\
\hline Syringic acid & + & - \\
\hline
\end{tabular}

Table 1c: $\mathrm{R}_{\mathrm{f}}$ values and colour reactions of Phenolic compounds on Paper Chromatograms

\begin{tabular}{|c|c|c|c|c|c|c|}
\hline \multirow[t]{2}{*}{ Compound } & \multicolumn{2}{|c|}{$R_{f}$ values in solvent } & \multicolumn{2}{|c|}{ U.V fluorescence } & \multirow[t]{2}{*}{ Silphanilic reagent } & \multirow[t]{2}{*}{ P-Nitraniline reagent } \\
\hline & 1 & 2 & Without $\mathrm{NH}_{3}$ & With $\mathrm{NH}_{3}$ & & \\
\hline Digallic acid & 0.29 & 0.69 & None & Blue violet & Violet & Violet \\
\hline Gallic acid & 0.45 & 0.66 & violet & Violet & Violet & Violet \\
\hline Ellagic acid & 0.02 & 0.28 & None & Blue green & Blue green & Blue green \\
\hline Aesculetin & 0.28 & 0.33 & white blue & Very bright blue & Brown & Grey \\
\hline Cis-p-coumaric acid & 0.42 & 0.77 & Light blue & Deep blue & Dark brown & Blue \\
\hline iso-chlorogenic acid & 0.01 & 0.31 & Faint blue & Duck egg green & Light orange & Brown \\
\hline chlorogenic acid & 0.01 & 0.76 & Faint blue & Duckegg green & Orange & Brown \\
\hline Caffeic acid & 0.06 & 0.38 & Blue & Bright blue & Buff & Light brown \\
\hline Protocatechuic acid & 0.05 & 0.58 & None & None & Buff & Light brown \\
\hline Gentistic acid & 0.14 & 0.68 & Bright blue & Yellow & Buff & Blue white \\
\hline Scopoletin acid & 0.30 & 0.51 & Bright blue & Very bright blue & Yellow & Brown \\
\hline Phloretic acid & 0.66 & 0.77 & None & None & Yellow & Purple white \\
\hline$\rho$-Hydroxy benzoic acid & 0.38 & 0.68 & None & None & Bright yellow & Light pink \\
\hline$\alpha$-Resorcyclic acid & 0.16 & 0.83 & None & None & Brown & Orange brown \\
\hline$\beta$ - Resorcyclic acid & 0.28 & 0.75 & None & None & Dark brown & Brown \\
\hline trans- $\rho$-coumaric acid & 0.50 & 0.45 & Light blue & deep blue & Light brown & Blue \\
\hline Vanillic acid & 0.78 & 0.57 & None & None & Orange & Purple \\
\hline $\mathrm{P}$-coumarylquinic acid & 0.97 & 0.64 & None & None & Light yellow & Yellow \\
\hline Cis- $\rho$-coumaric acid & 0.42 & 0.77 & Light blue & deep blue & Dark brown & Blue \\
\hline Melilotic acid & 0.51 & 0.76 & None & None & Orange yellow & Purple \\
\hline Cis-Ferulic acid & 0.89 & 0.65 & Light blue & Blue & Purple & Blue green \\
\hline trans-Ferulic acid & 0.80 & 0.31 & Light blue & Blue & Purple & Blue green \\
\hline
\end{tabular}

Volume 6 Issue 12, December 2017

www.ijsr.net

Licensed Under Creative Commons Attribution CC BY 
International Journal of Science and Research (IJSR)

ISSN (Online): 2319-7064

Index Copernicus Value (2016): 79.57 | Impact Factor (2015): 6.391

\begin{tabular}{|c|c|c|c|c|c|c|}
\hline Coumarin & 0.99 & 0.66 & None & None & Yellow & Violet \\
\hline Salycyclic acid & 0.93 & 0.31 & Dark blue & Dark violet & Yellow & Pink \\
\hline Cinnamic acid & 0.96 & 0.04 & None & None & Yellow & Green \\
\hline Syringic acid & 0.92 & 0.48 & None & None & red & Dark blue \\
\hline
\end{tabular}

Solvents: 1. Benzene : Acetic acid : Water(60:70:30);

2. Sodium formate : Formic acid : Water(10:1 :200)

\section{$\underline{\text { B. Flavonoids Compounds }}$}

\section{a) Extractive procedure}

The flavonoid compounds were extracted according to the method given by Markham (1982). About 5g of powdered plant material was extracted in two steps. First $18 \mathrm{ml}$ of Methanol and $2 \mathrm{ml}$ of water (9:1) were added, shaken well and kept for one day at room temperature. The supernatant solution of the extract was taken and transferred to another test tube. Secondly Methanol and water of $5 \mathrm{ml}$ each $(1: 1)$ was added to the remaining residue, stirred well and the mixture left for 24 hours. The two extracts were combined, mixed well and filtered through cotton wool. Later the filtrate was evaporated to about $1 / 3$ the original volume till most of the methanol was removed. The resultant aqueous extract was extracted with chloroform repeatedly for 3 times. The solvent extracted aqueous chloroform layer was evaporated to dryness under vaccum in a rotary evaporator. The dried residue was saturated with $1 \mathrm{ml}$ of $95 \%$ alcohol and stored in a dark place at low temperature.

\section{b) Identification}

The extracts containing flavonoids were separated in suitable quantities on Whatmann No.1 Chromatographic filter paper $(23 \times 29 \mathrm{~cm})$ adopting the ascending technique using the solvent system Iso-propyl alcohol : Ammonia $(25 \%)$ : Water(8:1:1:v/v/v) and n-butanol:acetic acid: water( $4: 1: 5 \mathrm{v} / \mathrm{v} / \mathrm{v})$ (top layer was used).The dried Chromatograms were examined under UV lamp and the fluorescent spots were marked. The papers while exposed to Ammonia Vapours were also observed under UV lamp and the new fluorescent regions were marked. The flavonoid compounds were identified by comparing the $\mathrm{R}_{\mathrm{f}}$ values and colours with those of the authentic samples on the Chromatograms. Co-Chromatographic studies were conducted with authentic markers to confirm the identification.

\section{Chromogenic spray reagents}

Diazotized sulphanilic acid reagent (Markham, 1982) $: 0.3 \%$ solution of sulphanilic acid in $8 \% \mathrm{HCl}(25 \mathrm{ml})$ was mixed with $5 \%$ Sodium nitrite solution $(1.5 \mathrm{ml})$ just before use. The Chromatographic sheets were sprayed with this mixture and with a $20 \%$ solution of anhydrous Sodium carbonate.

1\% Alcoholic ferric chloride: $1 \mathrm{~g}$ of Ferric chloride was dissolved in alcohol and made up to $100 \mathrm{ml}$.

1\% Alcoholic Aluminium chloride:1g of Aluminium chloride was dissolved in alcohol and made up to $100 \mathrm{ml}$, just before spraying of the chromatographic sheets.

Table 2a: Flavonoids

\begin{tabular}{|l|c|c|}
\hline \multirow{2}{*}{ Compoud } & \multicolumn{2}{c|}{ Terminalia pallida } \\
\cline { 2 - 3 } & Stem Bark & Fruit \\
\hline Quercetin & + & + \\
\hline Rutin & + & + \\
\hline Myricetin & + & + \\
\hline Luteolin & - & + \\
\hline Apigenin & + & + \\
\hline Orientin & - & - \\
\hline Vitexin & + & - \\
\hline
\end{tabular}

Table 2b: $\mathrm{R}_{\mathrm{f}}$ values and colour reactions of Flavonoids on Paper Chromatograms

\begin{tabular}{|c|c|c|c|c|c|c|c|}
\hline Compound & \multicolumn{2}{|c|}{$\mathrm{R}_{\mathrm{f}}$ values in solvent } & \multicolumn{2}{c|}{ U.V. fluorescence } & $\begin{array}{c}\text { Sulphanilic } \\
\text { Reagent }\end{array}$ & $\begin{array}{c}1 \% \text { Alcoholic } \\
\text { Ferric Chloride }\end{array}$ & $\begin{array}{c}1 \% \text { alcoholic } \\
\text { Aluminium Chloride }\end{array}$ \\
\hline & 1 & 2 & Without NH3 & With NH3 & & & \\
\hline Quercetin & 0.26 & 0.64 & yellow & Light yellow & Bright yellow & Green & Yellow \\
\hline Rutin & 0.03 & 0.57 & Orange brown & Yellow & Green & Olive & Grey yellow \\
\hline Myricetin & 0.07 & 0.43 & Yellow & Bright yellow & Light yellow & Olive & Grey yellow \\
\hline Luteolin & 0.44 & 0.78 & Dull yellow & Yellow & Light red & Pale green & Pale yellow \\
\hline Apigenin & 0.61 & 0.91 & Red brown & Red brown & Pink & Pale green & None \\
\hline Orientin & 0.78 & 0.31 & Yellow & Yellow green & Grey & None & None \\
\hline Vitexin & 0.91 & 0.42 & Dull yellow & yellow & Bright red & none & None \\
\hline
\end{tabular}

Solvents: 1 . Iso-propyl alcohol : Ammonia(25\%) : Water (8:1:1)

2. n-butanol: Acetic acid : Water(4:1:5)

\section{Amino acids}

\section{a) Extractive procedure}

Amino acids were extracted following the method of Das Chowdary et al., (1967). About $5 \mathrm{~g}$ of plant material was cut into small pieces and plunged immediately into a round bottomed flask containing $20 \mathrm{ml}$ of $80 \%$ Ethanol. It was reflexed for 30 minutes over a boiling water bath. The boiled material was ground in mortar using additional volumes of $10 \mathrm{ml}$ ethanol $80 \%$ (v) and centrifuged at $2000 \mathrm{rpm}$. The supernatant was collected and the Ethanol removed in vaccum. The aqueous extract was passed through Dowex $50 \mathrm{~W}-\mathrm{X} 8\left(\mathrm{H}^{+}\right.$from $\left.20-50 \mathrm{mesh}\right)$ column $(1 \times 10 \mathrm{~cm})$. the amino acids were eluted from the column with $50 \mathrm{ml}$ of $2 \mathrm{~N}$ Ammonium hydroxide. The elute was evaporated to dryness and the residue was saturated with $95 \%$ Ethanol $(1 \mathrm{ml})$.

\section{b) Identification}

The extracts containing amino acids were seperated on Whatmann No.1 Chromatographic filter paper $(23 \times 28 \mathrm{~cm})$

\section{Volume 6 Issue 12, December 2017}




\section{International Journal of Science and Research (IJSR) \\ ISSN (Online): 2319-7064}

Index Copernicus Value (2016): 79.57 | Impact Factor (2015): 6.391

employing two-dimensional ascending technique using the solvent system:

1) Sec. butanol : Formic acid : Water(75:13:12v/v/v)-1 ${ }^{\text {st }}$ direction.

2) Buffer saturated phenol $(1: 2 \mathrm{v} / \mathrm{v})-2^{\text {nd }}$ direction(6.3 $\mathrm{g}$ of Sodium citrate and $3.7 \mathrm{~g}$ of Potassium dihydrogen phosphate were dissolved in $100 \mathrm{ml}$ of distilled water. To this $200 \mathrm{ml}$ of distilled phenol was added)

The amino acids were identified based on comparision of $R_{f}$ values, colours and with those of authentic samples by cochromatographic studies.

\section{C) Chromogenic spray reagents}

Ninhydrin:It was prepared by dissolving $200 \mathrm{mg}$ of Ninhydrin in $98 \mathrm{ml}$ of $\mathrm{n}$-butanol with $2 \mathrm{ml}$ of glacial acetic acid.

Table 3a: Amino acids

\begin{tabular}{|l|c|c|}
\hline \multirow{2}{*}{ Compoud } & \multicolumn{2}{c|}{ Terminalia pallida } \\
\cline { 2 - 3 } & Stem Bark & Fruit \\
\hline Aspartic acid & + & + \\
\hline Arginine & + & + \\
\hline Asparagine & + & - \\
\hline$\alpha$-Alanine & + & - \\
\hline$\beta$-Alanine & + & + \\
\hline 2-Aminobutyric acid & - & + \\
\hline Cystaine & + & + \\
\hline Cystine & + & + \\
\hline Glutamic acid & - & - \\
\hline Glutamine & + & + \\
\hline Glycine & + & + \\
\hline Histidine & + & + \\
\hline Isoleucine & + & + \\
\hline Leucine & + & + \\
\hline Lycine & - & - \\
\hline$\gamma$-Methylene glutamic acid & + & + \\
\hline$\gamma$-Methylene glutamine & + & + \\
\hline Norleucine & + & - \\
\hline Ornithine & + & + \\
\hline Phenylalanine & - & - \\
\hline Proline & + & + \\
\hline Serine & + & - \\
\hline Threonine & + & - \\
\hline Tryptophan & + & - \\
\hline Valine & + & + \\
\hline Tyrosine & - & - \\
\hline
\end{tabular}

Table 3b: $\mathrm{R}_{\mathrm{f}}$ values and colour reactions of Amino acids on Paper Chromatograms

\begin{tabular}{|l|c|c|l|}
\hline \multicolumn{1}{|c|}{ Compound } & \multicolumn{2}{|c|}{$\begin{array}{c}\mathrm{R}_{\mathrm{f}} \text { values in } \\
\text { solvent }\end{array}$} & $\begin{array}{l}\text { Colour with } \\
\text { Ninhydrin }\end{array}$ \\
\hline L-Aspartic acid & 0.05 & 0.10 & Light violet \\
\hline DL-Arginine & 0.10 & 0.60 & Violet \\
\hline DLAsparagine & 0.19 & 0.41 & Violet \\
\hline$\alpha-A l a n i n e$ & 0.26 & 0.28 & Light violet \\
\hline$\beta$-Alanine & 0.42 & 0.77 & Deep violet \\
\hline DL-2-Aminobutyric acid & 0.55 & 0.70 & Light violet \\
\hline L-Cystaine & 0.38 & 0.61 & Deep violet \\
\hline L-Cystine & 0.23 & 0.53 & Violet \\
\hline L-Glutamic acid & 0.17 & 0.20 & Violet \\
\hline L-Glutamine & 0.14 & 0.82 & Violet \\
\hline L-Glycine & 0.09 & 0.38 & Violet \\
\hline L-Histidine & 0.08 & 0.52 & Violet \\
\hline DL-Isoleucine & 0.68 & 0.82 & Violet \\
\hline L-Leucine & 0.79 & 0.83 & Deep violet \\
\hline L-Lycine & 0.79 & 0.83 & Deep violet \\
\hline
\end{tabular}

Volume 6 Issue 12, December 2017 www.ijsr.net

Licensed Under Creative Commons Attribution CC BY

\begin{tabular}{|l|l|l|l|}
\hline$\gamma$-Methylene glutamic acid & 0.20 & 0.68 & Violet \\
\hline$\gamma$-Methylene glutamine & 0.30 & 0.71 & Violet \\
\hline DL-Norleucine & 0.96 & 0.68 & Violet \\
\hline DL-Ornithine & 0.04 & 0.27 & Light violet \\
\hline DL-Phenylalanine & 0.60 & 0.90 & Light violet \\
\hline L-Proline & 0.39 & 0.89 & Yellow \\
\hline DL-Serine & 0.20 & 0.23 & Deep violet \\
\hline DL-Threonine & 0.28 & 0.35 & Deep violet \\
\hline DL-Tryptophan & 0.50 & 0.76 & Violet \\
\hline DL-Valine & 0.59 & 0.77 & Deep violet \\
\hline L-tyrosine & 0.52 & 0.65 & Light violet \\
\hline
\end{tabular}

Solvents: 1 . Sec. butanol : Formic acid :Water(75:13:12)

2. Buffer: Phenol(1:2)

\section{E. Anthocyanidins}

\section{a) Extractive procedure}

The anthocyanidin constituents were extracted according to the method described by Harborne (1973).

About $5 \mathrm{~g}$ of plant material was immersed in $20 \mathrm{ml}$ of $2 \mathrm{~N} \mathrm{HCl}$ in a boiling test tube and heated for 30-40 minutes at $6100^{\circ} \mathrm{c}$. The extract was cooled and filtered. The filtrate was washed twice with $20 \mathrm{ml}$ of ethyl acetate to remove flavones. The remaining aqueous extract was further heated at $80^{\circ} \mathrm{c}$ for 3 minutes to remove the last traces of ethyl acetate. The pigment was re-extracted again with a small volume of Isoamyl alcohol. The Ethyl acetate extract was evaporated to dryness on a boiling water bath. The anthocyanidin in the residue was diluted with $1 \mathrm{ml}$ of $1 \%$ Methanolic $\mathrm{HCl}$ and preserved at low temperature in dark for future use.

\section{b) Identification}

The extracts containing anthocyanidins was separated on 23 x $29 \mathrm{~cm}$ Whatmann No.1 Chromatographic filter paper. Unidimensional Chromatographic ascending technique was employed with Conc. Hydrochloric acid, Formic acid, Water $(2: 5: 3 \mathrm{v} / \mathrm{w} / \mathrm{v})$ and $\mathrm{n}$-butanol : Acetic acid : water (4:1:5). The Chromatograms developed from the said solvent systems were taken out from the glass chambers and dried at room temperature. The fluorescent regions of dried papers were marked under UV light. The $\mathrm{R}_{\mathrm{f}}$ values and colours of the spots were determined by comparing with those of the authentic markers on the Chromatograms.

\begin{tabular}{|c|c|c|}
\hline \multirow{2}{*}{ Compoud } & \multicolumn{2}{|c|}{ Terminalia pallida } \\
\cline { 2 - 3 } & Stem Bark & Fruit \\
\hline Cyanidin & + & - \\
\hline Petunidin & - & - \\
\hline Delphinidin & + & + \\
\hline
\end{tabular}

Table 4b: $\mathrm{R}_{\mathrm{f}}$ Values and Colours of Anthocyanidins on Paper Chromatograms

\begin{tabular}{|c|c|c|c|c|c|}
\hline Compound & \multicolumn{2}{|c|}{$\begin{array}{l}\mathrm{R}_{\mathrm{f}} \text { values in } \\
\text { solvent }\end{array}$} & $\begin{array}{l}\text { Visible } \\
\text { colour }\end{array}$ & \multicolumn{2}{|c|}{ U.V. fluorescence } \\
\cline { 2 - 3 } \cline { 5 - 6 } & 1 & 2 & & without $\mathrm{NH}_{3}$ & with $\mathrm{NH}_{3}$ \\
\hline 1 & 0.38 & 0.68 & Magenta & pink & blue green \\
\hline 2 & 0.26 & 0.50 & Purple & mauve & Mauve \\
\hline 3 & 0.15 & 0.40 & Purple & mauve & blue green \\
\hline
\end{tabular}

Solvents : 1. Conc. Hydrochloric acid : Formic acid : Water $(2: 5: 3)$

2. n-butanol : Acetic acid : Water(4:1:5). 


\section{International Journal of Science and Research (IJSR) \\ ISSN (Online): 2319-7064}

Index Copernicus Value (2016): 79.57 | Impact Factor (2015): 6.391

\section{$\underline{\text { F. Lipids }}$}

\section{a) Extractive procedure}

Lipids were extracted following the method adopted by Hoppe and Heitefuss (1974).

A solvent mixture consisting of $30 \mathrm{ml}$ Chloroform, $60 \mathrm{ml}$ of Methanol and $20 \mathrm{ml}$ Water(1:2:0.8 v/v/v) was taken and allowed to boil. About $5 \mathrm{~g}$ of plant material was homogenized in the above solvent mixture. The contents were filtered and taken separately. The residual mixture was treated with $70 \mathrm{ml}$ Methanol and the filtrate taken. The residue was again washed with $100 \mathrm{ml}$ Chloroform. All the above filtrate mixtures were taken in a separating funnel and $90 \mathrm{ml}$ of water added. The mixture now contains Chloroform: Methanol: Water in the ratio of $2: 2: 1.8$ respectively and the mixture were allowed to settle. The lower lipid layer containing chloroform was separated and transferred into a breaker. The upper water layer was treated with $50 \mathrm{ml}$ of Chloroform successively for three times. All the extracted Chloroform layers were evaporated to dryness in a vacuum by rotary evaporation maintained at $40^{\circ} \mathrm{C}$. The residue was treated with $2 \mathrm{ml}$ of Benzene to remove the traces of chlorophyll if present. Now the final lipid residue was dissolved in $2 \mathrm{ml}$ of Chloroform and stored at low temperature in dark until use.

\section{b) Identification}

Thin layer plates were prepared by spreading a slurry of silicagel-G $(50 \mathrm{~g}$ in $100 \mathrm{ml}$ distilled water) to $105 \mathrm{~mm}$ thickness over thin glass plates. The glass plates were air dried and stored at room temperature. Before using, the plates were heated at $110^{\circ} \mathrm{c}$ for 30 minutes in a hot air oven for activation.

Using micropipette, one gram equivalent of lipid extract was taken and potted on TLC plates. The spotted areas were allowed for immediate dryness with the help of a drier. The dried plates were run in uni dimensional ascending Chromatography by using TLC glass chambers. The chambers were saturated with developing solvents one day before the plates were developed.

\section{Solvent systems}

1) Chloroform: Methanol: Acetic acid: Water (170:25:25:3 $\mathrm{v} / \mathrm{v} / \mathrm{v} / \mathrm{v})$

2) Acetone: Benzene: Water(91:30:8 v/v/v).

The plates were placed in airtight tanks. The developed plates were removed and dried at room temperature and exposed to Iodine vapours to visualize all the lipid compounds.

The TLC plates were sprayed with $25 \%$ Sulphuric acid reagent with the help of an automizer for the clear detection of various lipid layers. The lipids were identified by comparision of $\mathrm{R}_{\mathrm{f}}$ values, color and with those of authentic samples by Co-Chromatographic studies.

\section{c) Chromogenic spray reagent}

The TLC plates were sprayed with $25 \%$ Sulphuric acid and heated to $230^{\circ} \mathrm{c}$ for 15 minutes, and the colour observed. Glycolipids gave red brown while phospholipids gave bright, red and other lipids gave pale brown colour spots on white background.

Table 5 a: Lipids

\begin{tabular}{|l|c|c|}
\hline \multirow{2}{*}{\multicolumn{1}{|c|}{ Compoud }} & \multicolumn{2}{c|}{ Terminalia pallida } \\
\cline { 2 - 3 } & Stem Bark & Fruit \\
\hline Phosphatidyl serine & + & + \\
\hline Phosphatidyl inositol & + & + \\
\hline Phosphatidyl Clioline & + & + \\
\hline Phosphatidyl ethanolamine & + & - \\
\hline Digalactosyl diglyceride & - & - \\
\hline Phosphatidyl glycerol & - & + \\
\hline Sulphoquinovosyl diglyceride & + & + \\
\hline Monogalactosyl diglyceride & + & + \\
\hline Steryl glycoside & + & + \\
\hline
\end{tabular}

Table 5b: Rf values and colour reaction of lipids on thin layer Chromatograms

\begin{tabular}{|c|c|c|c|}
\hline Compound & $\begin{array}{c}\mathrm{R}_{\mathrm{f}} \text { values } \\
\text { in solvent }\end{array}$ & $\begin{array}{c}\text { Colour } \\
\text { with } \\
\text { iodine } \\
\text { vapours }\end{array}$ & $\begin{array}{c}\text { Colour } \\
\text { with } \\
\mathrm{H}_{2} \mathrm{SO}_{4} \\
(25 \%)\end{array}$ \\
\hline Phosphatidyl serine & 0.09 & + & + \\
\hline Phosphatidyl inositol & 0.13 & + & + \\
\hline Phosphatidyl Clioline & 0.18 & + & + \\
\hline Phosphatidyl ethanolamine & 0.23 & + & + \\
\hline Digalactosyl diglyceride & 0.33 & + & + \\
\hline Phosphatidyl glycerol & 0.41 & + & + \\
\hline Sulphoquinovosyl diglyceride & 0.57 & + & + \\
\hline Monogalactosyl diglyceride & 0.81 & + & + \\
\hline Steryl glycoside & 0.87 & + & + \\
\hline
\end{tabular}

Solvent : $\mathrm{CHCl}_{3}: \mathrm{MeOH}: \mathrm{HOAc}: \mathrm{H}_{2} \mathrm{O}(170: 25: 25.3)$.

\section{Physicochemical studies:}

For several years, the crude drugs were identified by comparison only with the standard descriptions available. But recently, due to advancement in the field of Pharmacognosy, various techniques are followed to the standardization of crude drugs. Among such techniques, ash and extractive values are considered very important in promoting the quality and in establishing the Pharmacopeial standards of the drug.

Substandard quality of many drugs is due to either faulty collection or incorrect storage. When the constituents of a drug cannot be readily estimated by any other means, ash and extractive values are very useful especially for their evaluation. To prove its acceptability as a drug, studies of ash and extractive values are basically required in determining the quality and purity of selected crude drug.

\section{Materials and Methods}

The physical constants like ash and extractive values were determined by standard methods (Anonymous, 1985 and Kokate, 1991).

\section{Experimental Studies}

\section{A. Determination of ash values}

The object of ashing crude drugs is to remove all traces of organic matter which may otherwise interfere in an analytical determination. The inorganic salts naturally occurring in drug or adhering to it or deliberately added to as

\section{Volume 6 Issue 12, December 2017}




\section{International Journal of Science and Research (IJSR) \\ ISSN (Online): 2319-7064}

Index Copernicus Value (2016): 79.57 | Impact Factor (2015): 6.391

a form of adulteration are removed by gradual incineration of the drug. Thus the residue remaining after incineration of the powdered drug is known as ash content. The ash values are a criterion to judge the identity or purity and quality of the crude drug.

\section{a) Determination of total ash}

Total ash usually consists of Phosphates, Silicates and Carbonates of Potassium, Calcium and Magnesium. About 2 gm of the air dried powdered drug was accurately weighed and taken in a tared silica crucible, which was previously ignited and weighed. The powdered drug was spread as a fine even layer at the bottom of the crucible. The crucible containing the drug was gradually incinerated in a muffle furnace by increasing the temperature. It was heat dull red hot until free from carbon or converted into ash. Later the crucible was allowed to cool and kept in desiccators. The residue was weighed the percentage of total ash calculated with reference to the air dried sample. The residue was weighed the percentage of total ash calculated with reference to the air dried sample. The procedure was repeated till constant result was obtained.

\section{b) Determination of acid insoluble ash}

Acid insoluble ash is a part of total ash insoluble in dilute Hydrochloric acid. The acid insoluble ash content is determined and recommended for certain drugs may be coated with dirt and sand. The total ash obtained as described above was treated with $25 \mathrm{ml}$ of $10 \%$ Hydrochloric acid and boiled for 5 minutes. The insoluble matter was filtered and collected on ashless filter paper (Whatman No.42) and the paper washed with hot water. The insoluble ash was ignited and weighed in a tared silica crucible. The acid insoluble ash of the drug was repeated to get constant results.

\section{c) Determination of water soluble ash}

The total ash obtained from the above process was boiled with $25 \mathrm{ml}$ of distilled water for 5 minutes. The insoluble ash was filtered through ash less filter paper (Whatman No.42). The residue was once again washed with water and ignited up to temperature not exceeding $450^{\circ} \mathrm{c}$ and converted into ash. The difference between the weight of total ash and insoluble matter represent the weight of water soluble ash. The percentage of water soluble ash was calculated with reference to the air dried drug.

\section{B. Determination of extractive values}

Extractive values indicate the nature of the constituents present in a crude drug. Based on the diversity in chemical nature and properties of the contents of the drug, various solvents were used for the determination of extractives. The solvents used for extraction dissolve appreciable quantity of substances desired. The methods used to find out the extractive values were as follows.

\section{a) Determination of alcohol soluble extract}

Alcohol is an ideal solvent frequently employed to determine various chemical contents like Tannins, Resins etc. Generally, Ethyl alcohol is used for determination of alcohol-soluble extractive. Dilute Alcohol a may also be used in some cases, depending upon solubility of constituents in a crude drug. In the present work, the author used $100 \mathrm{ml}$ of $90 \%$ Alcohol for determining crude drug was macerated with $100 \mathrm{ml}$ of $90 \%$ Alcohol in a stoppered flask for 24 hours. It was shaken frequently every 6 hours and allowed to stand to 18 hours. Then the extract was filtered rapidly through filter paper, taking precaution against loss of alcohol, about $25 \mathrm{ml}$ of the filtrate was evaporated to dryness in a tared flat bottomed shallow dish, transferred to the oven and dried at $105^{\circ} \mathrm{C}$ and weighed. The percentage of alcohol soluble extract was calculated with reference to the air dried drug.

Table 6: Ash value of various parts of Terminalia pallida

\begin{tabular}{|c|c|c|c|c|c|}
\hline S.No. & Plant species & Plant Parts & Total ash (\%) & Acid insoluble ash (\%) & Water insoluble ash (\%) \\
\hline \multirow{2}{*}{1.} & \multirow{2}{*}{ Terminalia pallida } & Stem bark & 8.65 & 0.15 & 0.4 \\
\cline { 3 - 6 } & & Fruit & 4.00 & 0.35 & 2.4 \\
\hline
\end{tabular}

Table 7: Extractive value of the stem bark and fruit of Terminalia pallida

\begin{tabular}{|c|c|c|c|c|c|c|}
\hline S.No. & Species & $\begin{array}{c}\text { Plant } \\
\text { Parts }\end{array}$ & $\begin{array}{c}90 \% \text { alcohol soluble } \\
\text { extract }(\% \mathrm{w} / \mathrm{w})\end{array}$ & $\begin{array}{c}\text { Water soluble } \\
\text { extract }(\% \mathrm{w} / \mathrm{w})\end{array}$ & $\begin{array}{c}\text { Chloroform soluble } \\
\text { extract }(\% \mathrm{w} / \mathrm{w})\end{array}$ & $\begin{array}{c}\text { Pet.Ether soluble } \\
\text { extract }(\% \mathrm{w} / \mathrm{w})\end{array}$ \\
\hline 1 & Terminalia & Stem bark & 28.8 & 32 & 1.2 & 1.6 \\
\cline { 3 - 7 } & pallida & Fruit & 18 & 4.8 & 0.4 & 0.8 \\
\hline
\end{tabular}

\section{Antibacterial Activity}

The presence of antimicrobial substances in the higher plants provide a source of inspiration for novel drug compounds as plants derived medicines have made significant contribution towards human health. The antimicrobial compounds from plants may inhibit microbial growth by different mechanism than those presently used antimicrobials and may have a significant clinical value in treatment of resistant microbial strains. Therefore, random screening of plants for active chemicals is as important as the screening of ethnobotanically targeted species (Principle, 1989).

\section{Materials and Methods}

Collection of medicinal plants: Selected medicinal plant, Terminalia pallida, has been used in the present study and it was collected from Veligonda hill range, Eastern Ghats, Nellore Dt, Andhra Pradesh, India.

Bacterial Cultures: The bacterial cultures were procured from the Department of Microbiology, Sri Venkateswara Institute of medical Sciences (SVIMS), Tirupati. Pathogenic Gram positive bacteria such as Bacillus subtilis, Klebsiella pneumoniae, and Gram negative bacteria Proteus vulgaris, Pseudomonas aeruginosa, were maintained on nutrient agar slants at $4^{0} \mathrm{C}$ until further used for experimental studies. 


\section{International Journal of Science and Research (IJSR) \\ ISSN (Online): 2319-7064}

Index Copernicus Value (2016): 79.57 | Impact Factor (2015): 6.391

\section{Preparation of the medium}

\section{Nutrient Agar media (P.H 7.0)}

For the preparation of 1 lt of Nutrient Agar media ingredients like $1.5 \mathrm{~g}$ of beef extract, $1.5 \mathrm{~g}$ of yeast extract, 5 $\mathrm{g}$ of peptic digest of animal tissue and $5 \mathrm{~g}$ of sodium chloride were weighed and added in $500 \mathrm{ml}$ of distilled water and heated with agitation to dissolve the constituents. Finally, the volumes were made upto $1 \mathrm{lt}$. Before the addition of agar $(15 \mathrm{~g})$ the $\mathrm{pH}$ of the medium was adjusted to 7.0 by adding few drops of $0.1 \mathrm{~N} \mathrm{NaOH}$ or $\mathrm{HCl}$ using digital pH meter ( Elico Pvt. Ltd., Hyderabad). These were then sterilized by autoclaving at $15 \mathrm{lbs}$ pressure at $120^{\circ} \mathrm{C}$ for 15 min; cooled to $40^{\circ} \mathrm{C}$ and approximately $20 \mathrm{ml}$ of medium was poured to each $90 \mathrm{~mm}$ sterilized petridish.

\section{Preparation of inoculum:}

Bacteria: 18 hrs old bacterial broth cultures were used as inoculae after adjusting its population to $10^{6} \mathrm{CFU} / \mathrm{ml}$ (Colony Forming Units) using $0.9 \%(w / v)$ sterile saline by the method described by Forbes et al.,(1990).

Preparation of plant extract: The methanolic extracts of the four selected medicinal plants were prepared by dissolving $10 \mathrm{gm}$ of fine powder of each medicinal plants separately in $100 \mathrm{ml}$ of methanol solvent. The contents were kept in orbitary shaker for $48 \mathrm{~h}$. Then the extract was filtered and it is dried in hot air oven at $40^{\circ} \mathrm{C}$. Then the extract was stored under refrigeration at $4^{0} \mathrm{C}$ for further studies.

Preparation of sterile disc: Whatman's No.3 filter paper was punched into $5 \mathrm{~mm}$ disc form and they sterilized, each sterile disc was incorporated individually with $20-60$ $\mathrm{mg} / \mathrm{ml}$ of extracts using micropipette. Precautions were taken to prevent the flow of the solvent extract from the discs to the outer surface. The condensed extracts were applied in small quantities on discs and they were allowed to dry in air. Then they were stored at $4^{0} \mathrm{C}$.

\footnotetext{
Assay of antimicrobial activity using Disc diffusion method :The antimicrobial activity was performed by employing the disc diffusion method adopted by Bauer et al., (1966) and Cruickshank (1968). The $20 \mathrm{ml}$ of sterilized Muller Hinton Agar was poured into sterile petriplates, after solidification, $100 \mu \mathrm{l}$ of fresh culture of human pathogens were swabbed on the respective plates. Sterile discs of Whatman No. 1 filter paper of about $6 \mathrm{~mm}$ were prepared. The discs were kept over the agar plates using sterile forceps at various concentrations $(20,40$, and $60 \mathrm{mg} / \mathrm{ml})$. Streptomycin $10 \mathrm{mg} / \mathrm{ml}$ containing disc used as standard control. The plates were incubated for $24 \mathrm{~h}$ at $37^{\circ} \mathrm{C}$ and the diameter of the inhibition zones was recorded. The assessment of antimicrobial activity was based on measurement of inhibition zones formed around discs. A zone of inhibition around the disc indicates that the
}

compounds, which diffused into the agar from the disc, inhibited the growth of the organism.

\section{Results}

Present investigation, antibacterial activity of Terminalia pallida on pathogenic bacterial strains, the plant exhibited significant antibacterial activity. For the Methanol extract of Terminalia pallida at the concentration $60 \mathrm{mg} / \mathrm{ml} P$. vulgaris $(16.5 \mathrm{~mm})$ was more susceptible, followed by $K$. pneumonia (15.8mm), B.subtilis $(15.4 \mathrm{~mm})$ and $P$. aeruginosa $(13 \mathrm{~mm})$.

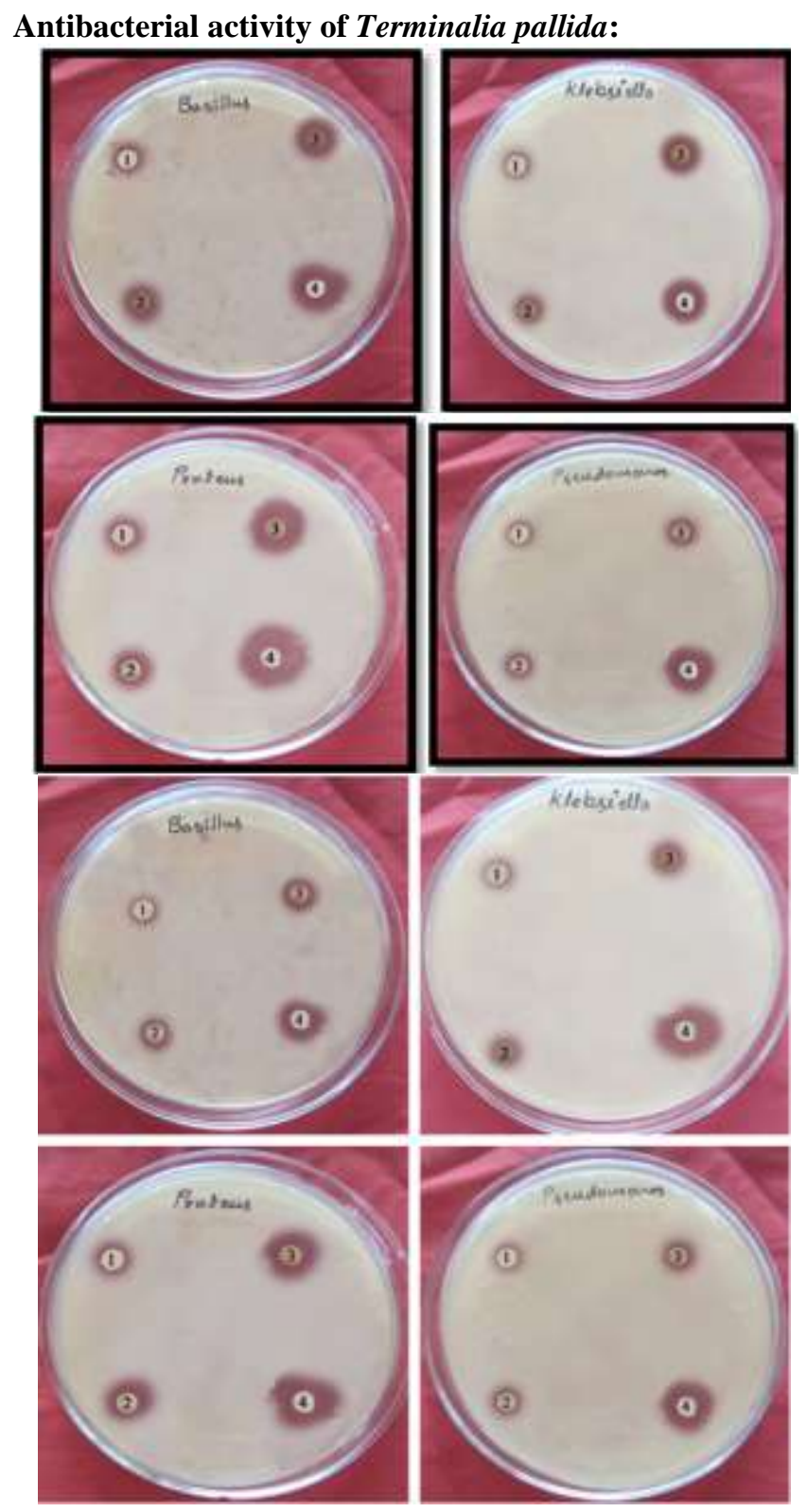




\section{International Journal of Science and Research (IJSR) \\ ISSN (Online): 2319-7064}

Index Copernicus Value (2016): 79.57 | Impact Factor (2015): 6.391

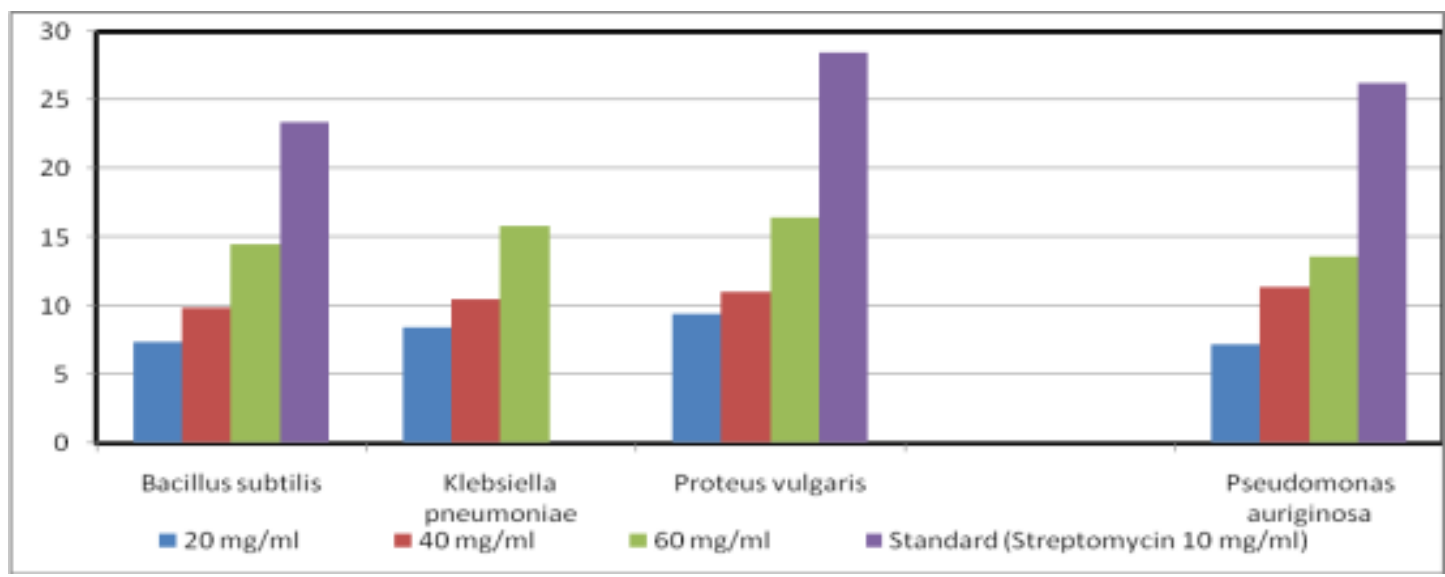

\begin{tabular}{|c|c|c|c|c|c|}
\hline S. No & Name of the microorganism & $20 \mathrm{mg} / \mathrm{ml}$ & $40 \mathrm{mg} / \mathrm{ml}$ & $60 \mathrm{mg} / \mathrm{ml}$ & Standard (Streptomycin $10 \mathrm{mg} / \mathrm{ml}$ ) \\
\hline 1. & Bacillus subtilis & $7.4 \pm 0.44 \mathrm{~mm}$ & $9.84 \pm 0.63 \mathrm{~mm}$ & $14.5 \pm 0.28 \mathrm{~mm}$ & $23.45 \pm 0.65 \mathrm{~mm}$ \\
\hline 2. & Klebsiella pneumoniae & $8.5 \pm 1.2 \mathrm{~mm}$ & $10.5 \pm 0.6 \mathrm{~mm}$ & $15.82 \pm 0.24 \mathrm{~mm}$ & $24.4 \pm 0.53 \mathrm{~mm}$ \\
\hline 3. & Proteus vulgaris & $9.4 \pm 0.39 \mathrm{~mm}$ & $11.04 \pm 0.56 \mathrm{~mm}$ & $16.5 \pm 0.35 \mathrm{~mm}$ & $28.53 \pm 0.74 \mathrm{~mm}$ \\
\hline 4. & Pseudomonas auriginosa & $7.2 \pm 0.68 \mathrm{~mm}$ & $11.4 \pm 0.57 \mathrm{~mm}$ & $13.65 \pm 0.56 \mathrm{~mm}$ & $26.25 \pm 0.36 \mathrm{~mm}$ \\
\hline
\end{tabular}

\section{References}

[1] Abdul Rasheed Miah (1995)“Fruit Decoction - Its Soluble Constituents"

[2] Anonymous (1969), Satyavathi, Gupta (1987), Nagaraju\&Rao (1989), Vedavathy et al,(1997) "Medicinal plants use for Diseases".

[3] Ahmad I, Mehmood Z, Mohammad F.. Screening of some Indian medicinal plants for their antimicrobial properties. J Ethnopharmacol,. 1998; 62: 183-193.

[4] Anonymous ( 1985)\&Kokate( 1991)Ash and Extractied Values of Physical Constant Values Adopted by Standard Method

[5] Agarwal, S.R,( 1981). Trees, flowers and fruits in Indian folk songs, folk proverbs and folk tales.In Jain, S.K. (Ed.), Glimpses of Indian Ethno-botany, 3 - 12.

[6] Ayyappan, A. (1948). Report on the socio-economic studies on aboriginal Tribes of the province of Madras. Government press, Madras.

[7] Amalraj, V.A, (1983).Secondary plant constituents Science Reporter.June issue, CSIR, New Delhi.

[8] Arora, R.K. (1996) Role of Ethno botany in the conservation and use of plant genetic resources in India in S.K. Jain (ed.) Ethno biology in Human Welfare 287296 Deep publications, New Delhi.

[9] Anuradha S. Upadhye, V.D. Vartak and M.S. Kumbhojkar, (1994) Ethno - Medico Balakrishnan.N.P\& K. Subrahmanyam(1960).A New Species of Euphorbia from India. Bull. bot. Surv. India 2:175 - 176.

[10] Balandrin.M.F\&Klocke.J.A.(1985) Natural plant chemicals: sources of Industrial and Medicinal Material. Science 228: $1154-1160$.

[11] Balandrin MFJ, Kjocke A, Wurtele E. Natural plant chemicals: sources of industrial and medicinal materials. Science, 1985; 228: 1154- 1160.

[12] Balasubramanian, P. \& S.N. Prasad. (1996) Ethnobotany and conservation of Medicinal plants of Irulas of Nilgiri Biosphere reserve, In S.K. Jain. (ed.) Ethnobiology in Human Welfare.271-273.Deep publications, New Delhi.
[13] Banber (1857) Agency Areas of North Circars\&NallaMalai Hills.

[14] Banerjee.L.K, Rao.T.A, Sastry.R.K\&Ghosh D 2002 Diversity of Coastal Plants Communicaties in india Botanical Survey of India, Kolkatta.

Volume 6 Issue 12, December 2017 www.ijsr.net 